\title{
Spatial Planning of Biogas Stations in Estonia
}

\author{
Kristjan Piirimäe, Viktoria Blonskaja, Enn Loigu \\ Tallinn University of Technology, Department of Environmental Engineering, Ehitajate tee 5, Tallinn, 19086, Estonia.
}

\begin{abstract}
Developing and implementing renewable energy systems such as biogas from anaerobic digestion process (AD), based on national and regional biomass resources, will increase the security of the national energy supply and diminish dependency on imported fuels. For Estonia, the EU Directive for renewable energy targets has been set to $25 \%$ by 2020 . Data about the municipal biodegradable waste produced in Estonia during 2002-2012 were collected. The subject of the analysis was different types of biodegradable waste from landfills, biodegradable waste from food production companies, sludge from waste treatment plants as well as waste from livestock farms, trade companies, gardens and parks in Estonia. The wastes volumes, qualities, and their energy potential were estimated. The GIS (geographic information systems) model was applied for the spatial planning of biogas stations in Estonia.
\end{abstract}

Keywords: biogas potential; biodegradable wastes; GIS model; logistical parameters; spatial planning of biogas stations.

\begin{tabular}{|ll|}
\hline Nomenclature \\
GIS $\quad$ Geographic Information System \\
MSW & Municipal Solid Waste \\
\hline
\end{tabular}

\section{Introduction}

Anaerobic digestion is widely used as a renewable energy source because the process produces methane and carbon dioxide rich in biogas that is suitable for energy production, helping to replace fossil fuels. Suitable sources for the anaerobic degradation process are e.g. beet, potatoes, maize, straw, wood, animal waste (slurry, stomach/intestine content, fats), whey, flotation sludge, slops from fermentation, straw, garden wastes, grass, silage, fish and soya oils, evaporation condensation, alcohol, food remains and sewage sludge [1-12]. These materials can be received from the food industry, trade companies, pharmaceutical industry, slaughterhouses, harvest remains, farmyards, gardens, parks, wastewater treatment plants. Substrate composition is a major factor in determining the methane yield and methane production rates from the digestion of biomass.

Today, most European countries are strongly dependent on fossil energy imports from regions rich in fossil fuel sources such as Russia and the Middle East. Developing and implementing renewable energy systems such as biogas from anaerobic digestion process (AD), based on national and regional biomass resources, will increase the security of the national energy supply and diminish dependency on imported fuels. The EU Directive for Renewable Energy has set targets for the rates of renewables in energy consumption as high as 25,40 and $23 \%$ by 2020 , for Estonia, Latvia and Lithuania-, respectively [13]. Biogas production from waste during the anaerobic digestion process is one way to decrease the biodegradable fraction in municipal waste and increase the share of renewables in total energy consumption.

As far as sources of biogas are scattered, locating their anaerobic digestion facilities serves as a spatial planning challenge. For instance, to minimise transportation costs, biogas stations should be placed in the vicinity of sources. To provide a concrete solution for this strategy, we developed a GIS model, which proposes locations for biogas stations according to the locations of their sources. The model also concludes quantities of available sources as well as biogas production potential. 


\subsection{Study area}

To build up and test the model, we chose the whole of Estonia, populated by 1.3 million inhabitants, covering $45,000 \mathrm{~km}^{2}$, as the study area. While performing the analysis [14], Estonia had five small rural manure gas stations (Fig. 1). Three stations generated gas from industrial wastewater while four stations used urban wastewater. Finally, three stations produced gas from landfills. At the same time, several new small stations were in the planning or construction phase. The

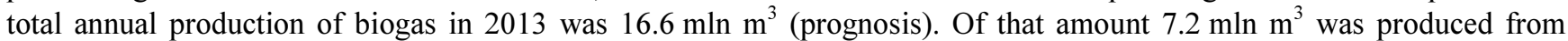
manure and $6.5 \mathrm{mln} \mathrm{m}^{3}$ from landfills. In total, $82 \%$ of the produced gas was used for the co-generation of electricity and heat. None of the existing biogas stations supplied natural gas pipelines.

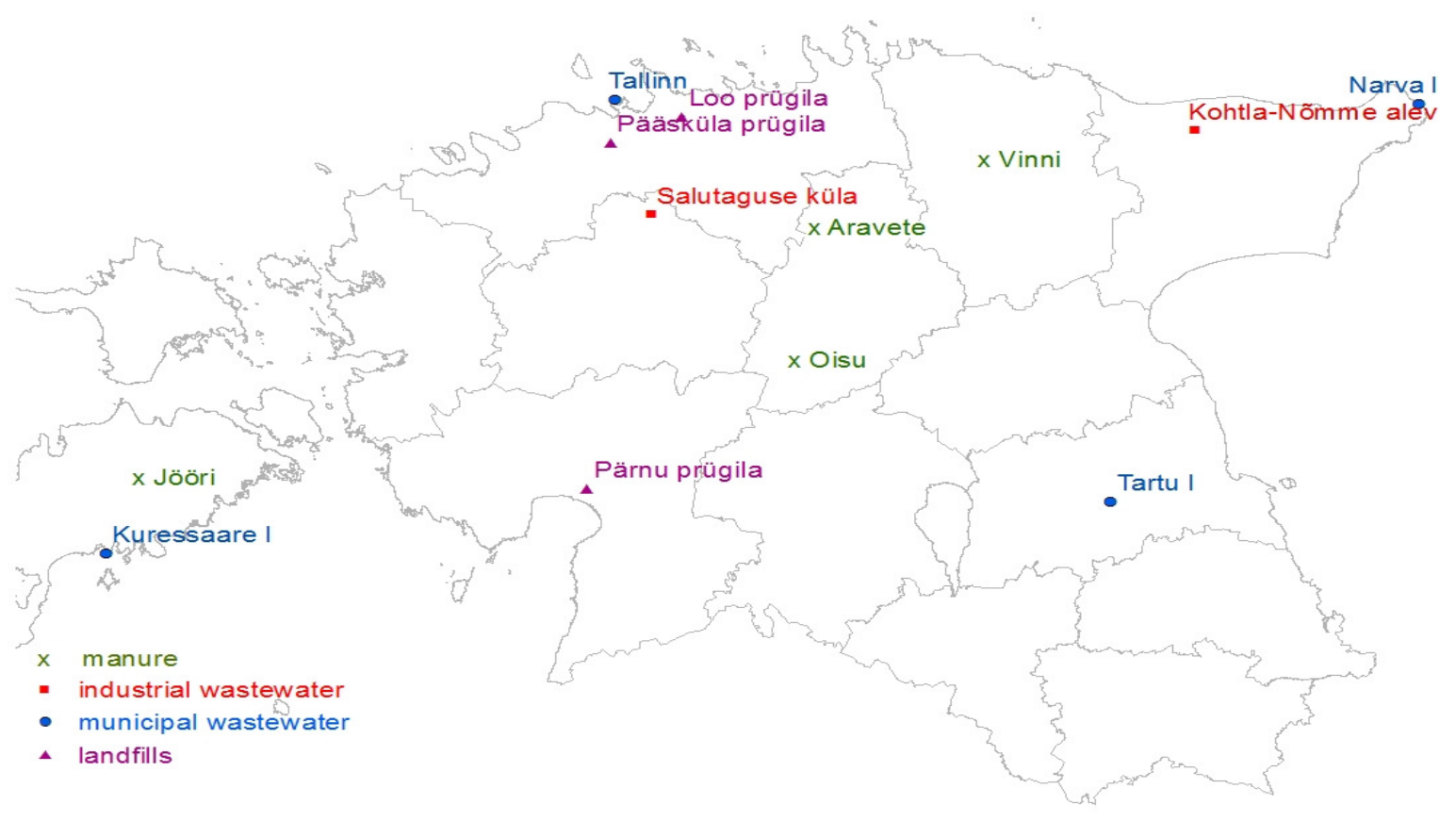

Fig. 1. Study area, indicating locations of the existing biogas stations

\section{Material and methods}

We collected data about the municipal biodegradable waste produced in Estonia during 2002-2012. Data sources were taken from the Estonian Environment Information Centre, Estonian Statistical Office and the databases of Tallinn University of Technology. Among the acquired data, the most significant were: municipal, food production, trading, terrace and gardening wastes (including cemetery waste) from 4,694 sources (towns, villages and other sources); manure from 292 farms; and 145 sources of wastewater sludge. During the anaerobic digestion process the organic waste from these sources may be converted to biogas. The method of statistical analysis using Mathcad 2001 Professional software was applied for the data analysis.

Using ESRI ${ }^{\circledR}$ ArcMapTM 10.1, the input data were rasterised to pixels with the size of $1 \mathrm{~km}^{2}$ each. This generated GIS layers, indicating annual generated biogas potential in each Estonian $\mathrm{km}^{2}$ from each type of source. The model also considered the existing manure gas stations and their collection zones, which were assumed to be round circles, the station in the centre point,- and with the a radius of $5 \mathrm{~km}^{2}$. The existing collection zones were cut out from the map of biogas potential. Similarly, the model considered the existing other biogas stations and their sources as already occupied.

To propose locations for future biogas stations, areas under water bodies, wetlands as well as protected areas were disregarded. Hence, proposed a work zone for the planning of new stations, outside of these unsuitable areas. For each of these work zone cells, the model calculated the amount of available biogas within the collection radius of $30 \mathrm{~km}$. By combining this result with the map of Estonia`s 15 counties, the model drafted 15 stations to the locations that had the biggest amount of potential biogas within the collection radius. These draft stations, which failed to meet the annual threshold of $10 \mathrm{mln} \mathrm{m}^{3}$ of gas, were left out from further analysis. Then, in order to avoid overlapping collection zones, only the draft stations with the greatest potential within the radius of $50 \mathrm{~km}$ were left in the analysis.

By using the map of roads, the model calculated the friction distance from each gas source to the nearest station, whereby the friction value for road pixels was 1 while for the other pixels 3 . In other words, transportation of $1 \mathrm{~km}$ outside a road was assumed to be equal to transportation along the road of $3 \mathrm{~km}$. The total transportation need for each gas-providing cell was calculated by multiplying the friction distance with the amount of potential gas. The efficiency of each station was calculated by dividing the total available potential gas within the collection radius with the transport volume. 
The same GIS analysis was also repeated separately for manure, excluding other biogas sources. For manure gas stations, the annual threshold of available resource within the collection zone was set to $9 \mathrm{mln} \mathrm{m}^{3}$ of gas.

\section{Results and discussion}

The average annual quantity of different types of biodegradable waste, their theoretical biogas potential and economically usable biogas quantity were estimated and presented in Table 1. The researchers [15] consider that only a certain percentage of waste is economically profitable to use for biogas production in Estonia. For the theoretical amount of biogas calculation, the average values of gas formation during the anaerobic digestion process were taken from existing research [6, 16]. As shown in Table 1, the theoretical biogas production was estimated as $521 \mathrm{mln} \mathrm{m}^{3}$ tons per year, but only $25 \%$ $\left(130.4 \mathrm{mln} \mathrm{m}^{3}\right)$ may be estimated as economical resource.

Table 1. Theoretical potential of biogas production

\begin{tabular}{|c|c|c|c|c|}
\hline Type of waste & $\begin{array}{l}\text { Average quantity } \\
\text { of waste } \\
\text { (mln.tons/year) }\end{array}$ & $\begin{array}{l}\text { Theoretical biogas potential } \\
\left(\mathrm{mln} \cdot \mathrm{m}^{3} / \text { year }\right)\end{array}$ & Biogas, usable (\%) & $\begin{array}{l}\text { Economically usable } \\
\text { biogas quantity } \\
\left(\mathrm{mln} \cdot \mathrm{m}^{3} / \text { year }\right)\end{array}$ \\
\hline $\begin{array}{l}\text { Biomass from unused } \\
\text { lands [17] }\end{array}$ & 2,069 & 280,411 & 20 & 56 \\
\hline Manure(dry matter) & 2,415 & 161,772 & 30 & 49 \\
\hline Sludge( dry matter) & 0,029 & 14,629 & 50 & 7 \\
\hline $\begin{array}{l}\text { Another biodegradable } \\
\text { MSW/landfill gas }\end{array}$ & 0,090 & 9,017 & 80 & 7 \\
\hline $\begin{array}{l}\text { Agricultural waste are } \\
\text { waste from horticulture, } \\
\text { forest, hunting, and } \\
\text { fishing }\end{array}$ & 0,225 & 21,972 & 30 & 7 \\
\hline $\begin{array}{l}\text { Biodegradable waste of } \\
\text { food industry }\end{array}$ & 0,148 & 26,540 & 10 & 3 \\
\hline $\begin{array}{l}\text { Agricultural energy crops- } \\
\text { maize }\end{array}$ & 0,027 & 5,050 & 20 & 1 \\
\hline $\begin{array}{l}\text { Terrace- and gardening } \\
\text { waste }\end{array}$ & 0,007 & 1,237 & 20 & 0.3 \\
\hline \multirow[t]{2}{*}{$\begin{array}{l}\text { Biodegradable waste of } \\
\text { trade }\end{array}$} & 0,009 & 0,699 & 10 & 0.1 \\
\hline & Total & 521,327 & & 130,4 \\
\hline
\end{tabular}

The major potential sources for biogas production are biomass from unused lands, manure, sludge, agricultural waste and waste from food production. Gardening waste, sheep and trade companies can provide little biogas. Today, the main resource for biogas production in Estonia can be manure and sludge.

A huge amount of biomass from unused lands can theoretically produce a huge amount of biogas [17]. All unused lands in Estonia were analysed, but in the GIS model they were not taken into account, as in spatial planning the main aspect is point sources of pollution.

Of various kinds of domestic animals, cattle and pigs prevailed in the study area, while the number of cattle and pig farms; providing more than $0.5 \mathrm{mln} \mathrm{m}^{3}$ of potential manure gas was almost equal. One of the pig farms, however, hosted as many as 60,000 animals. Compared to pigs, cattle were more scattered to smaller herds. Livestock was more concentrated to central and south parts of the study area.

Of other sources, food production, municipal waste and wastewater sludge appeared most significant, providing at least a couple of locations with biogas potential more than $0.5 \mathrm{mln} \mathrm{m}^{3}$. However, all the three largest suppliers of wastewater sludge were already in use for sludge gas production.

The remaining analysed biogas sources did not provide any supplier with over $0.5 \mathrm{mln} \mathrm{m}^{3}$ of biogas potential. The largest supplier of gardening waste held $0.3 \mathrm{mln} \mathrm{m}^{3}$ of annual biogas potential while the largest amount from trade companies possessed $0.4 \mathrm{mln} \mathrm{m}^{3}$. However, scattered over the study area, all the considered suppliers provided a significant contribution to potential stations. Although the number of large potential suppliers, that annually provide over $0.5 \mathrm{mln} \mathrm{m}^{3}$ of biogas- was limited to ca 30, the total number of potential suppliers, was several thousands, spreading relatively evenly over the study area. The chosen preconditions for suitable land cover for biogas stations allowed such instalments in most of the study area (Fig. 2). The largest constraints were national parks. 


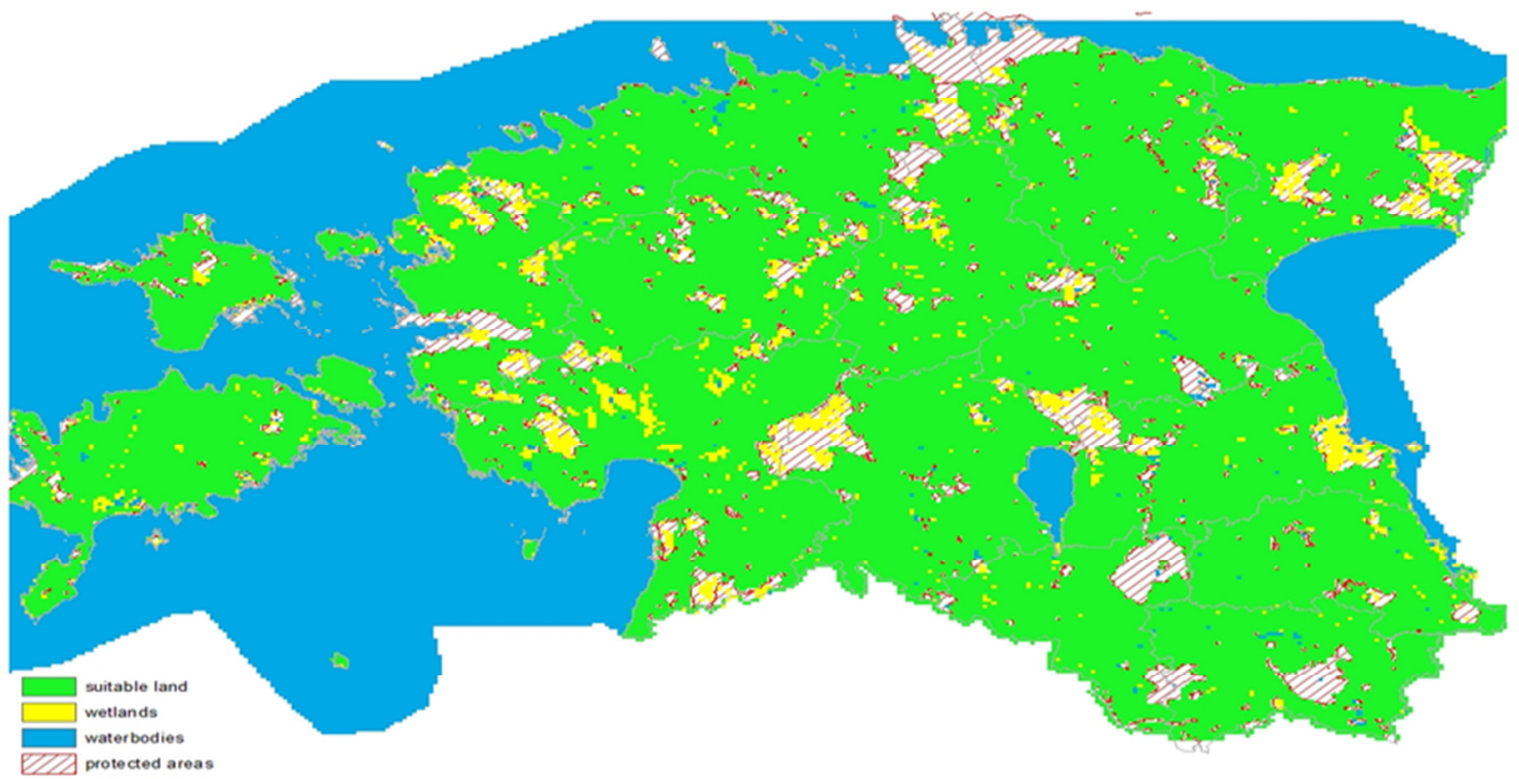

Fig. 2. Landcover preconditions for biogas stations

Within the defined collection radius, $30 \mathrm{~km}$, five separate large zones peaked, each promising more than $16 \mathrm{mln} \mathrm{m}^{3}$ of biogas production (Fig. 3). These zones located (1) outside Tallinn to the south, (2) around Tamsalu in Lääne-Viru county, (3) east from Paide town in Järva county, (4) the northern part of Viljandi county between Võhma and lake Võrtsjärv, and (5) the Puurmani area in the southern border of Jõgeva county. However, as the potential collection areas of these five zones partly overlapped, the model proposed only three biogas stations: the first one near Kohila town, on the border between Harju and Rapla counties, the second in Tamsalu parish in Lääne-Viru County, and the third in Kolga-Jaani parish, Viljandi County. Each of these stations would have approximately $20 \mathrm{mln} \mathrm{m}^{3}$ of biogas sources annually around the collection zone. Outside these three collection zones, the model did not find any pixel having at least the threshold amount of potential biogas within $30 \mathrm{~km}$.

If solely considering manure as biogas source, the model proposed four stations. However, the annual biogas availability of each of these stations was between $10 \mathrm{mln}$ and $18 \mathrm{mln} \mathrm{m}^{3}$. While two of these stations (Tamsalu and Kolga-Jaani) were located in the same places when considering all sources, the other two places were new: near Käru on the border between Rapla and Järva counties, as well as Kullamaa parish, on the border between Lääne and Rapla counties.

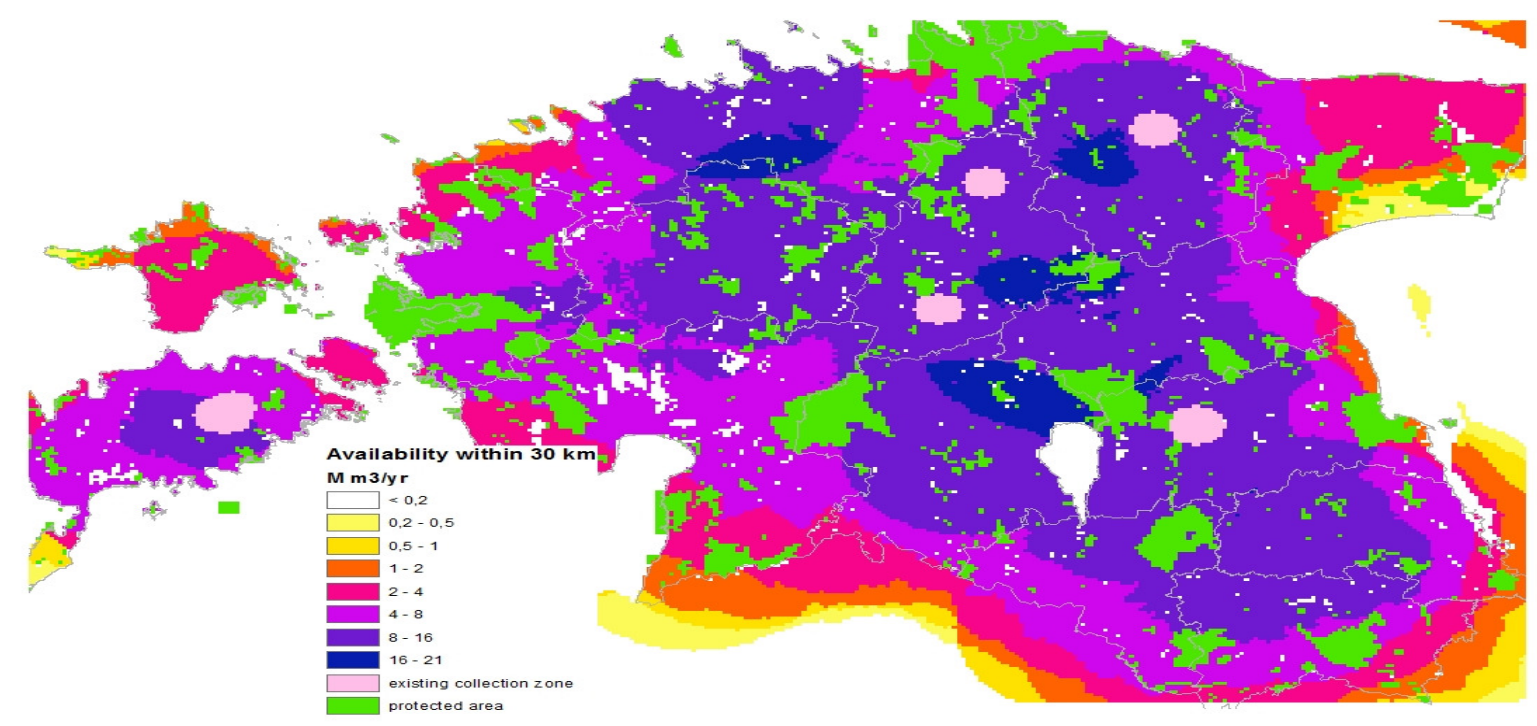

Fig. 3. Availability of potential biogas in collection radius

All three stations would collect their organic material from various sources, predominantly from cattle and pig manure, food production and municipal waste (Fig. 4). Large sources, providing more than $0.5 \mathrm{mln} \mathrm{m}^{3}$ each, cannot feed more than half of the total provision. Hence, most of the sources were small and scattered in the collection zones. Most sources were 
located between 20 and $35 \mathrm{~km}$ from the station. The collection efficiency of the proposed stations would be between 1.1 and $1.4 \mathrm{~m}^{3}$ of biogas per $\mathrm{x} \mathrm{km}$ of raw material collection. The best efficiency was found for the Kolga-Jaani station in South Estonia.

This article demonstrates a model to spatially plan biogas stations in the vicinity of available raw material. Also, the model aids to estimate the amount of available raw material. Yet, the presented approach, however, ignored other spatial planning factors such as natural gas pipelines for additional supply, the vicinity of consumers, workforce, other supporting infrastructure, etc. Moreover, the presented model version ignored several significant potential biogas sources such as wood, grass and landfills. The proposed parameters, such as collection radius and the required threshold of available raw material require further analysis. However, all these shortcomings could be overcome with just some extension and specification of the presented concept.

As biogas sources in Estonia are scattered, the collection is challenging. To collect annually $20 \mathrm{mln} \mathrm{m}^{3}$, more than 50 single sources should be involved in the collection system within a radius of $30 \mathrm{~km}$ of a well-located station. This requires smart logistical solutions as well as a complicated set of agreements with providers. An alternative approach, however, would be the continuation of the business-as-usual with small stations, based on a single or just few suppliers.

The largest potential source is manure, and a particular prominent potential supplier is Viiratsi pig farm in Viljandi County. Correspondingly, the model predicts that the biggest potential biogas production rate as well as the best efficiency would be close to that pig farm, in Kolga-Jaani parish.

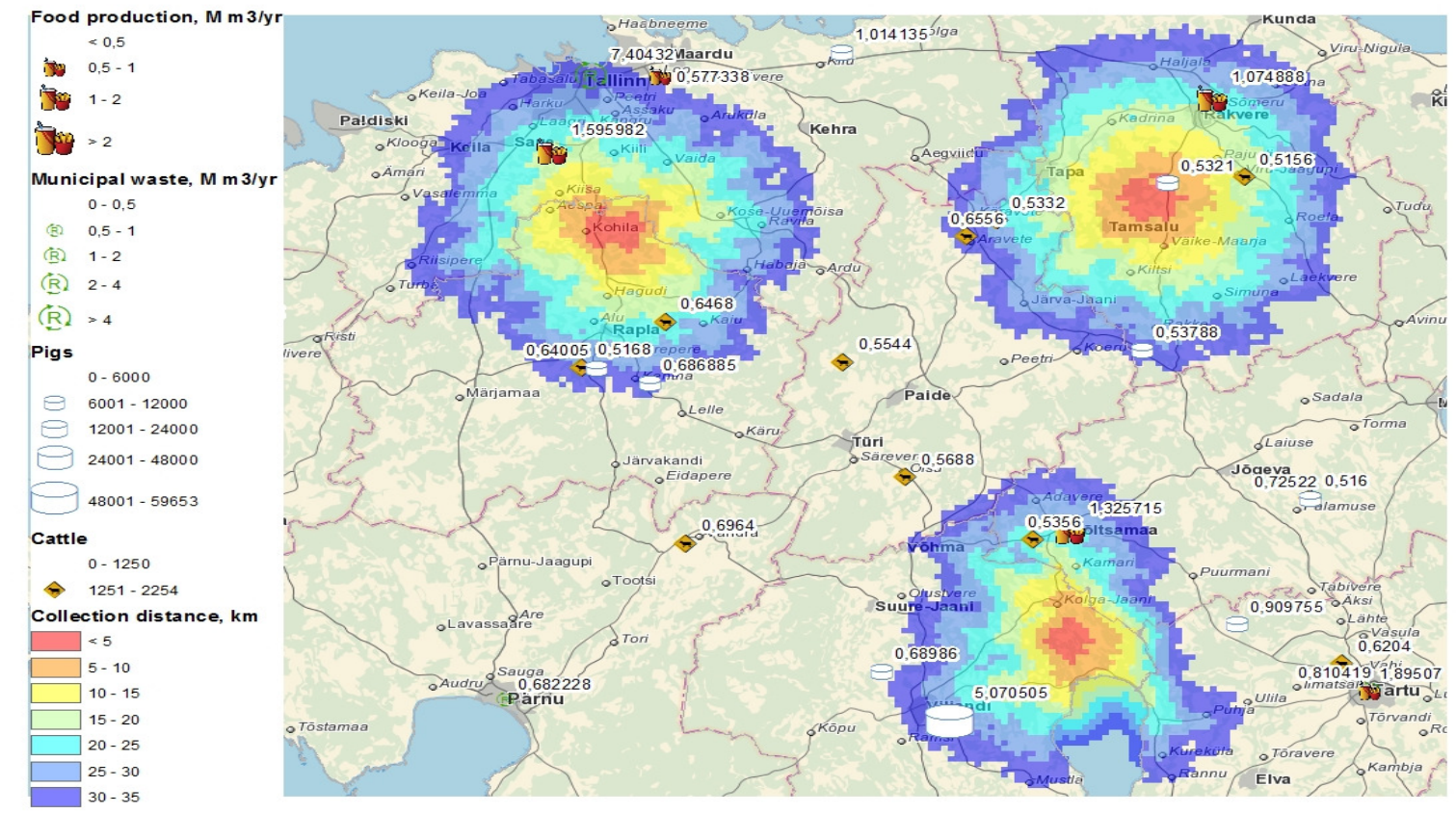

Fig. 4. Biogas collection distance for proposed stations and single sources exceeding $0.5 \mathrm{mln} \mathrm{m}^{3}$ of potential annual biogas production

\section{Conclusion}

Estonia has enough organic waste for energy production. The major potential sources are biomass from unused lands, manure, wastes of food production, agricultural waste and sludge. Gardening waste, sheep and trade companies can produce small amount of biogas. Today, the main resource for biogas production in Estonia is manure and sludge.

The GIS model was applied for the spatial planning of biogas stations in Estonia. This model suggests the locations of biogas stations according to the locations of their sources.

The biogas sources in Estonia are scattered and the waste collection system requires logistical solutions as well as complicated set of agreements with providers. An alternative approach may be as a small biogas plant, based on a single or just a suppliers.

\section{Acknowledgements}

This work was financially supported by the International Project SUSBIO VIR459. 


\section{References}

[1] Astals, S.; Ariso, M.; Galí, A.; Mata-Alvarez, J. 2011. Co-digestion of pig manure and glycerine: Experimental and modelling study, Journal of Environmental Management 92: 1091-1096. http://dx.doi.org/10.1016/j.jenvman.2010.11.014

[2] Mata-Alvarez, J.; Mace, S.; Llabres, P. 2000. Anaerobic digestion of organic solid waste. An overview of research achievements and perspectives, Bio resource Technology 74: 3-16. http://dx.doi.org/10.1016/S0960-8524(00)00023-7

[3] Sosnowski, P.; Wieczorek, A.; Ledakowicz, S. 2003. Anaerobic co - digestion of sewage sludge and organic fraction of municipal solid wastes, Advances in Environmental Research 73: 609-616. http://dx.doi.org/10.1016/S1093-0191(02)00049-7

[4] Neves, L.; Ribeiro, R.; Oliveira, R.; Alves, M. M. 2006. Enhancement of methane production from barley waste, Biomass and Bioenergy 30: 599-603. http://dx.doi.org/10.1016/j.biombioe.2005.12.003

[5] Macias-Corral, M.; Samani, Z.; Hanson, A.; Smith, G.; Funk, P.; Yu, H.; Longworth, J. 2008. Anaerobic digestion of municipal solid waste and agricultural waste and the effect of co-digestion with dairy cow manure, Bio-resource Technology 99: 8288-8293. http://dx.doi.org/10.1016/j.biortech.2008.03.057

[6] Fountoulakis, M.; Drakopoulou, S.; Terzakis, S.; Georgaki, E.; Manios, T. 2008. Potential for methane production from typical Mediterranean agroindustrial by-products, Biomass and Bioenergy 32(2): 155-161. http://dx.doi.org/10.1016/j.biombioe.2007.09.002

[7] Fountoulakis, M. P. 2010. Co-digestion of sewage sludge with glycerol to best biogas production, Waste Management 301: 849-1853

[8] Parawira, W.; Read, J. S.; Mattiasson, B.; Björnsson, L. 2008. Energy production from agricultural residues: High methane yields in pilot-scale twostage anaerobic digestion, Biomass and Bioenergy 32(1): 44-50. http://dx.doi.org/10.1016/j.biombioe.2007.06.003

[9] El-Mashad, H.; M.; Zhang, R. 2010. Biogas production from co-digestion of dairy manure and food waste, Bio resource Technology 101: $4021-4028$. http://dx.doi.org/10.1016/j.biortech.2010.01.027

[10] Álvarez, J. A.; Otero, L.; Lema, J. M. 2010. A methodology for optimising feed composition for anaerobic co-digestion of agro-industrial wastes, Bioresource Technology 101: 1153-1158. http://dx.doi.org/10.1016/j.biortech.2009.09.061

[11] Astals, S.; Ariso, M.; Galí, A.; Mata-Alvarez, J. 2011. Co-digestion of pig manure and glycerine: Experimental and modelling study, Journal of Environmental Management 92: 1091-1096. http://dx.doi.org/10.1016/j.jenvman.2010.11.014

[12] Ashekuzzaman, S. M.; Poulsen, T. G. 2011. Optimization feed composition for improved methane yield during anaerobic digestion of cow manure based waste mixture, Bio resource Technology 102: 2213-2218. http://dx.doi.org/10.1016/j.biortech.2010.09.118

[13] Directive 2009/28/EC of the European parlament and of the Council -on the promotion of the use of energy from renewable sources and amending and subsequently repealing Directives 2001/77/EC and 2003/30/EC. Official Journal of the European Union, L 140/16, 5.6.2009.:16-47.

[14] Pitk, P. 2013. Eesti Biogaasi Assotsiatsiooni ja projekti Baltic Manure teabe päev: Biogaasi aktuaalsed küsimused anno 2013/Estonia's Baltic Manure Biogas Association and Project Information Day: Biogas topical issues anno 2013. Available from Internet: http://eestibiogaas.ee/wpcontent/uploads/2013/08/Eesti-biogaasi-sektor-2013.pptx

[15] Background Paper on Biogas Sector in Estonia: Current Status and Development Needs. 2010:27. Available from Internet: http://www.lote.ut.ee/orb.aw/class=file/action=preview/id=882699/Background+paper+on+Biogas+Sector+in+Estonia_Current+Status+and+Develop ment+Needs.pdf

[16] Normak, A.; Vollmer, E.; Orupõld, K.; Kaasik, A.; Kask, Ü. 2008. Käsiraamat, Biogaasi tootmine ja kasutamine. Käsiraamat on lühendatud versioon originaalist.Handbook,. / Biogas production and utilization. The handbook is a shortened version of the original/Handreichung. Biogasgewinnung und-nutzung. 3., überarbeitete Auflage Gülzow, 2006. /Tallinn: Eesti Põllumeeste Keskliit. 157p.

[17] TUT (Tallinn University of Technology). Biomassi tehnoloogiauuringud ja tehnoloogiate rakendamine Eesti. / Biomass technology research and application of technologies in Estonia. Report No.7028.2008. Available from Internet: http://www.bioenergybaltic.ee/bw_client_files/bioenergybaltic/public/img/File/Lep7028VVFinalB.pdf 